\title{
家族性にみられた異所性褐色細胞腫例
}

東京慈恵会医科大学泌尿器科学教室 (主任：大石幸彦教授）
仲田浄治朗 大石 幸彦 小野寺昭一
五十嵐 宏 西田 篤
東京慈恵会医科大学青戸病院内科学教室 (主任：望月正武教授)
木 下 知 子 望 月 正 武

\section{A CASE OF ECTOPIC FAMILIAL PHEOCHROMOCYTOMA}

Jojiro Nakada, Yukihiko Oishi, Shoichi Onodera, Hiroshi Igarashi

and Atsushi Nishida

Department of Urology, Jikei University School of Medicine

(Director: Prof. Yukihiko Oishi)

Tomoko Kinoshita and Seibu Mochizuki

Department of Internal Medicine, Jikei University Aoto Hospital

(Director: Prof. Seibu Mochizuki)

This is a report of the occurrence of familial ectopic pheochromocytoma in two brothers, whose father had bilateral adrenal pheochromocytoma. Both brothers complained of hypertension. In the first case, a 22 -year-old man presented with much higher than normal norepinephrine. Abdominal CT and chest CT scanning and ${ }^{123} \mathrm{I}-\mathrm{MIBG}$ scintigraphy revealed an extraadrenal tumor in the chest on the bilateral adrenal grands. Bilateral adrenectomy was performed. In the second case, the 20-year-old brother was found to have an abdominal mass that was diagnosed as ectopic pheochromocytoma originating in the intra-abdominal paraaorta according to abdominal CT scanning and ${ }^{131}$ I-MIBG scintigraphy. The tumor was resected.

Key words: familial pheochromocytoma, ectopic pheochromocytoma

\begin{abstract}
要旨：家族性の褐色細胞腫例で兄弟共に異所性に腫瘍がみられたのは稀であり報告する。症例 1.22 歳, 男性．発汗，高血圧の精査で受診した．家族歷は，父に両側性褐色細胞腫の既往がある．内分泌検査で 血中ノルアドレナリンが高值であった。腹部エコー, CT, MRI で両側副腎部に一致して腫瘤がみられ, 胸部 CT で後縦隔に腫瘤がみられた。 ${ }^{123} \mathrm{I}-\mathrm{MIBG}$ シンチグラフィーでも胸部および両側副腎部に集積像 が認められた。褐色細胞腫の診断で両側副腎摘出術を施行した．症例 2 ．20歳，男性で症例 1 の弟であ る. 高血圧を主訴として受診した. 血中ノルアドレナリンが高值であり, CT では腹部大動脈と左腎下極 の間に球形の腫瘤がみられた。MRI，MIBG シンチグラフィーでも同部位に腫熘が確認され異所性の褐 色細胞腫と診断し, 腫湟摘出術を施行した。 キーワード：家族性褐色細胞腫，異所性褐色細胞腫
\end{abstract}

\section{緒言}

家族性褐色細胞腫は1943年に Hyman ら 最初に報告された。本邦においては，全国集計では褐 色細胞腫患者の家族内発症は7.1〜 7.3\%と記載されて いる ${ }^{23)}$. 家族性発生例は両側副腎部に発生する場合が 多いが，兄弟で両側副腎部および胸腔内に発生した症 例と腹部大動脈周囲に異所性に発生した褐色細胞腫例 を経験した。その父親も褐色細胞腫で副腎を摘出して
おり，家族性であること及び兄弟の 2 症例とも副腎外 異所性褐色細胞腫がみられ報告する。

\section{症例}

症例 $1: 22$ 歳, 男性.

主訴：高血圧の精査.

現病歴：1994年 8 月頃, 咽頭腫脹, 発熱がみられ近 医を受診した.高血圧も指摘され腹部エコーを施行し， 両側副腎部に腫瘤がみられたため依頼された。 
既往歴：特記すべきことなし。

家族歴：父は両側性褐色細胞腫で左副腎摘出術を施 行母方には，副腎疾患はみられない。

現症：血圧132/60～168/124. 脈拍80～100/分, 整. 胸腹部に異常所見なし。

臨床検査成績：尿，血液一般検查は正常範囲。内分 泌学的検查；血中アドレナリン $40 \mathrm{pg} / \mathrm{ml}(<100 \mathrm{pg} /$ $\mathrm{ml})$, ノルアドレナリン $4,317 \mathrm{pg} / \mathrm{ml}(100 \sim 450 \mathrm{pg} / \mathrm{ml})$, ドーパミン $17 \mathrm{pg} / \mathrm{ml}(<20 \mathrm{pg} / \mathrm{ml})$. 血中ノルアドレナ リンが高值であった，甲状腺，副甲状腺機能検查は正 常範囲であった。

画像検査：腹部 CT では両側副腎は著明に腫大し, 造影剂により造影効果を認め血管の豊富な腫瘤と思わ れた(図 1 ). 腹部 MRIの T1冠状断面像で両側腎の上 極に7〜 8cm の腫瘤がみられたＧＧ-DTPAにより腫 瘤の充実部はよく造影された。胸部 CTでは大動脈の 後方, 後緹隔に腫瘤が認められた (図 2)。 ${ }^{123}$ IMetaiodobenzylguanidine (MIBG) シンチグラフィー では, 両側副腎部および後縦隔腫瘍部と一致し胸腔内 にも異常集積像が認められた(図 3 )。頸部超音波検查 では, 甲状腺, 副甲状腺には腫溜はみられなかった。両 側副腎および胸腔内の多発性褐色細胞腫と診断した。

手術の 2 週間前より $\alpha 1$ 受容体遮断剂メシル酸ドキ サゾシン（カルデナリン）と $\beta$ 受容体遮断剤酒石酸入 トプロロール（セロケン）を投与し，両側副腎腫瘤の 摘出を1993年10月 5 日に施行した。

手術所見：肋骨弓下獚切開で経腹的に，下行結腸外 緑より後腹膜腔に到達し左副腎腫瘤を，ついで右副腎 腫瘤は肝下面より後腹膜腔に入り摘出した．腫瘤の大 きさは, 右副腎は $4 \times 8 \times 11 \mathrm{~cm}, 210 \mathrm{~g}$ あり,左副腎は $4 \times$ $8 \times 9 \mathrm{~cm}, 175 \mathrm{~g}$ であった。

図 1 症例 1 の腹部 CT。両側副腎は著明に腫大して おり，造影剤によりよく造影されている $(\rightarrow)$.

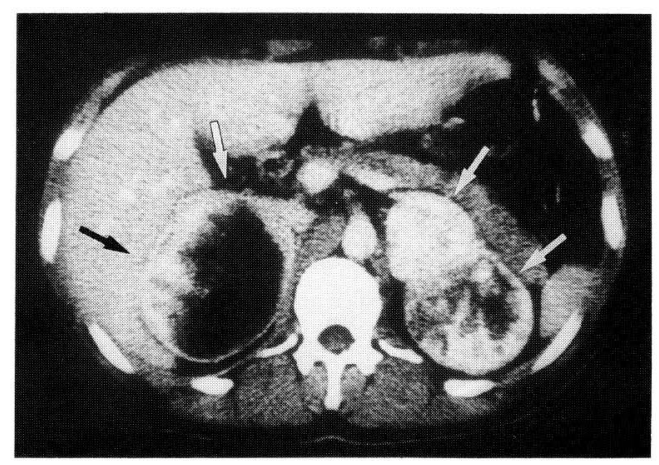

病理組織検查：被膜と実質に沿って細胞質が豊富で 顆粒状の alveolar な腫湯像がみられ褐色細胞腫と診 断した。細胞構築に異常所見はなく, 核の異型性や細 胞分裂像の所見はそしいことなどから，組織学的には 悪性所見は認められなかった。

術後経過：胸腔に腫瘤が残存するせいか術後10日目 でも血中ノルアドレナリンは $1,274 \mathrm{pg} / \mathrm{ml}$ みられ，血 圧は208/110 136/78で $\alpha 1$ 受容体遮断剤を投与した。 しかし血圧は徐々に下降して現在は降圧剤は使用して

図 2 症例 1 の胸部 CT. 後縌隔に腫瘤がみとめられ る $\rightarrow$.

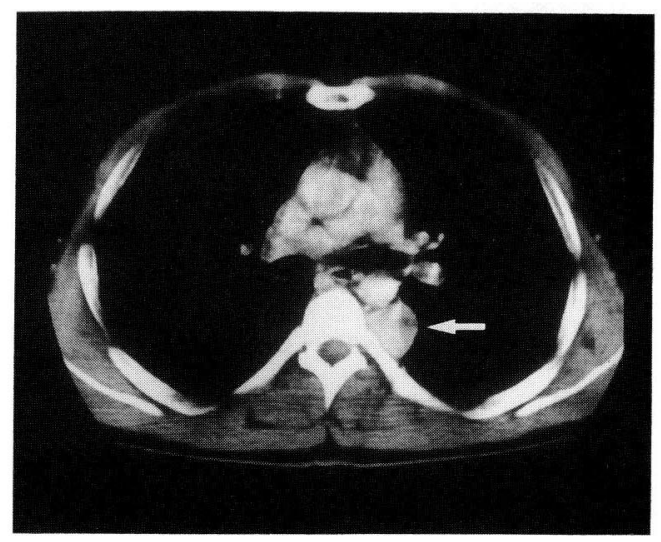

図 3 症例 $10^{123} \mathrm{I}-\mathrm{MIBG}$ 検査. 両側副腎部および胸 腔内に異常集積像がみられる.

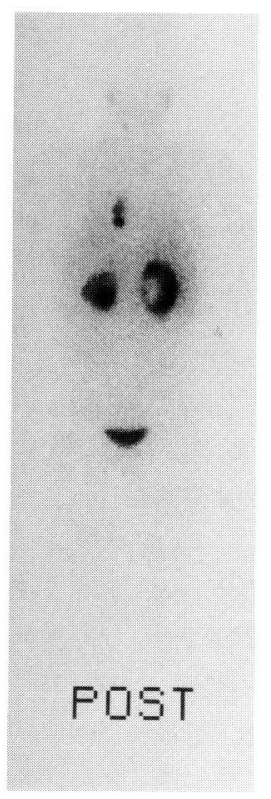


図 4 症例 2 の腹部 CT. 腹部大動脈と左腎下極の間 に直径約 $5 \mathrm{~cm}$ の球形な腫瘤がみとめられる $(\rightarrow)$.

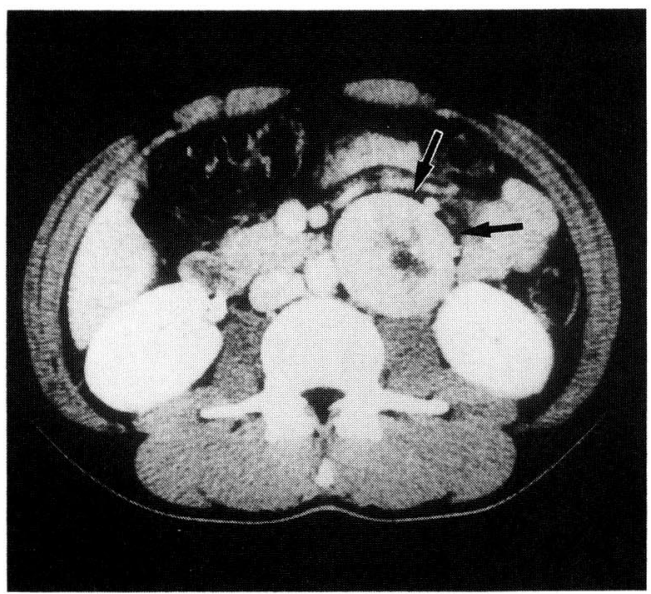

いない.両側副腎摘除のため, ステロイド補充療法とし て,ハイドロコーチゾン $35 \mathrm{mg} /$ 日を投与している.胸腔 内腫瘤は, 本人の強い希望があって経過観察中である. 症例 $2: 20$ 歳, 男性.

主訴：高血圧および副腎腫瘤の精査.

現病歴：痛例 1 の弟で, 家族性発生の褐色細胞腫の 有無を調べるため近医を受診した。血圧は $153 / 73$ みら れ腹部超音波検査で左副腎腫瘍が疑われ当院に紹介さ れた。小児期より時に発汗, 頭痛, 胸部圧迫感がみら れた。

既往歴：特記すべきことなし.

身体所見：胸腹部には異常所見なし。

臨床検査成績：尿，血液一般検査では血清カルシウ $\triangle 5.7 \mathrm{mEq} / l(4.0 \sim 5.2 \mathrm{mEq} / l)$, 血清無機リン $2.3 \mathrm{mg} /$ $\mathrm{dl}(2.5 \sim 4.5 \mathrm{mg} / \mathrm{dl})$ と軽度の高カルシウム血症と低り ン酸血症がみられた. 内分泌学的検查；血中アドレナ リン $18 \mathrm{pg} / \mathrm{ml}$, ノルアドレナリン $2,390 \mathrm{pg} / \mathrm{ml}$, ドーパ ミン $12 \mathrm{pg} / \mathrm{ml}$. 血中ノルアドレナリンが高值であった. 副甲状腺ホルモンのインタクト PTH $120 \mathrm{pg} / \mathrm{ml}$ (15〜 50pg/ml) と高值であった。

画像検査：腹部 CT では腹部大動脈と左腎下極の間 に直径約 $5 \mathrm{~cm}$ の腫瘤がみられた。内部構造は一部 low dencityであったが，造影剂により全体によく造影さ れ(図 4). ${ }^{131}$ I-MIBG シンチグラフィーでは腹部左側 に 1 力所, 高集積が認められた. 頸部 CT 検査, 副甲 状腺シンチグラムでは, 腫瘤はみられなかった。 以上 より異所性褐色細胞腫および副甲状腺機能元進症と診 断した。
術前に $\alpha 1$ 受容体遮断剂（カルデナリン）を投与し 1994年3月15日に手術を施行した。

手術所見：肋骨弓下，横切開で腹腔に到達した。腫 瘤は直下に触れ，下腸骨膜静脈の内側および下行結腸 外縁を切開し後腹膜腔に入り腫瘤を摘出した。摘出物 の大きさは $4.5 \times 5 \times 5 \mathrm{~cm}, 57 \mathrm{~g}$ で扊白色の充実性腫瘤 であった。

病理組織学検査：光顕像では胞巣状あるいは索状の 細胞配列からなり，実質細胞は微細顆粒状の明るい胞 体を持つ多棱形または類円形をなす細胞がみられた。 悪性所見はみられず異所性褐色細胞腫と診断した。

手術後経過：術後 3 日日のノルアドレナリンは536 $\mathrm{pg} / \mathrm{ml}$ と高值であったが, 術後 10 日目には $246 \mathrm{pg} / \mathrm{ml}$ と正常值に復した。1994年 6 月には正常血圧となり経 過は順調である，副甲状腺機能元運症については，無 症状であり本人の希望もあり経過観察中である.

\section{考察}

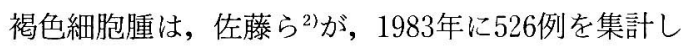
ているように珍しい疾患ではない.自験例は 3 人兄弟 で, 次男，3男の本症例抢よび父親も褐色細胞腫で副 腎を摘出しており遺伝性の濃厚な褐色細胞腫例であ る. 本邦での家族性発生の頻度は佐藤ら 2 は526例中15 家系38人で7.1\%と報告している。

褐色細胞腫の腫瘍の局在は本邦報告例では竹田ら ${ }^{3)}$ は非家族性では，両側副腎部が451例中27例 $6.0 \%$ で， 副腎外扝よび副腎十副腎外の症例が451例中89例, $19.7 \%$ みれたと報告している。一方，家族性発生例

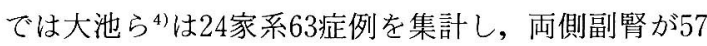
例中 34 例 $59.6 \%$ と高く，副腎外および副腎十副腎外に みられた症例が57例中 4 例 $7.0 \%$ であったと述べてい る。家族性発生例の褐色細胞腫の腫晹の局在特徵は, 両側性発生例が多く異所性発生例が少ない傾向にあ る.症例 1 では両側性副腎由来の褐色細胞腫がみられ, さらに胸腔内後縦隔隔にも異所性に発生し多発性で あった。症例 2 では腹部大動脈周囲に異所性に発生し ていた，家族性異所性褐色細胞腫例で記載の明らかな のは自験例を含め表 1 のごとく 8 家系 9 例であった. 元弟例で異所性に腫崵の発生がみられたのは非常に稀 である。

症例 1 は, 両側副腎腫啺に対し両側副腎摘出術を施 行したが，両側副腎摘出によりステロイド剂を補充せ ねばならないことから，一側のみを摘出したという報 告もみられる ${ }^{5}$. 本症例の父も他院で両側副腎由来の 褐色細胞腫を指摘されて，一側のみを摘用している。 
表 1 家族性異所性褐色細胞腫の本邦報告例

\begin{tabular}{|c|c|c|c|c|c|c|}
\hline NO. & \multicolumn{2}{|c|}{ 報告者 } & 初発年噛 & 性別 & 腫 瘍 部 位 & 文 \\
\hline 1 & 湯浅ら & $(1985)$ & 10歳 & 女 & 両側副腎 (初発), 左腎下極十胸部緹隔 (再発) & 日内会誌, 74, 1125-1132 \\
\hline 2 & 中川ら & (1987) & 13 & 女 & 腹部大動脈周囲 & 泌尿紀要，33，985-992 \\
\hline 3 & 八木ら & (1989) & 34 & 男 & 左副腎 (初発), 左腎門部 2 ケ所(再発) & 日臨外医会誌，50, 1625-1630 \\
\hline 4 & 清水ら & (1989) & 57 & 男 & 左副腎 (初発), 左腎門部 2 ケ所(再発) & 臨放, 34, 1055-1058 \\
\hline 5 & Kogawa & (1990) & 49 & 男 & 両側副腎 (初発), 腹部大動脈周囲 (再発) & 内分泌外科, 7, 425-431 \\
\hline 6 & 樋口ら & $(1992)$ & 13 & 女 & 胸部後縦隔 & 小児科臨床，45，2563-2567 \\
\hline 7 & 伊豫田ら & $(1994)$ & 19 & 男 & 左副腎部 +Zuckerkandl 小体部 & 日臨外医会誌，55,3195-3200 \\
\hline 8 & 自験例 & (1995) & 22 & 男 & 両側副腎十胸部後縦隔 & \\
\hline 9 & 自験例 & (1995) & 20 & 男 & 腹部大動脈周囲 & \\
\hline
\end{tabular}

褐色細胞腫のみを摘出し CUSA を用いることにより 正常副腎組織を温存したという報告もみられる ${ }^{6)}$.し かし本症例では，正常副腎部は腫瘍と一塊となってお り，剥離は困難で，また根治性の意味からも両側副腎 を摘出した. 術後のステロイド補充療法として, Cushing 症候群の術後管理に準じ7), 手術直後はハイドロ コーチゾン $200 \mathrm{mg} /$ 日を投与し, 現在はハイドロコーチ ゾン $35 \mathrm{mg} /$ 日の維持量投与している. 両側副腎摘出症 例で, 感冒時に十分なステロイドホルモンの服用がで きず preshock 状態になったという報告もみられ5)，ス テロイド服用に対する本人の十分な理解と緊急時のス テロイド補充の対応が必要である。

家族性褐色細胞腫の場合には, 甲状腺髄様癌を合併 する Sipple 症候群さらに副甲状腺病変を合併する場 合, 多発性内分泌腺症 IIA 型に分類され甲状腺や副甲 状腺疾患を検索する必要がある ${ }^{8)}$. 症例 1 では, 甲状 腺, 副甲状腺に病変はみられなかったが, 症例 2 では 副甲状腺機能六進症がみられ多発性内分泌腺症 IIA の亜型と思われる.甲状腺, 副甲状腺疾患についても, 今後も長期的に経過観察を要する. 褐色細胞腫の再発 頻度は，緒家の報告により様々であるが Remine ら ${ }^{9)}$ は9.5\% と報告している. 本邦では八木ら ${ }^{10)}$ は再発性褐 色細胞腫を 10 症例集計し，そのうち 3 例が家族性であ り再発性の頻度は高く, 再発がみられた場合は家族性 発症を念頭に置く必要があると述べている。

家族性発症をみる褐色細胞腫は発現性の高い常染色 体優性遺伝である. 自験例では遺伝子レベルでの検討 は施行していないが, 家族性発生をみる褐色細胞腫で は染色体 $1 ， 11$ に障害がみられるとの報告や MEN II 型では染色体異常が6p, 16q, 20p12, 22p11などに存在 することが報告されている11). 今後, 褐色細胞腫の病態
をより明らかにするためには，遺伝子レベルでの解析 を行い検討する必要があると思われた。

\section{文 献}

1) Hyman, A. and Mencher, W.H.: Pheochromocytoma of the adrenal gland. J. Urol., 49, 755-776, 1943.

2）佐藤辰男, 大石誠一, 岩岡大輔, 梅田照久：褐色細 胞腫. 日本臨床一本邦臨床統計集一, $41,879-890$, 1983.

3）竹田亮裕, 宮森 勇, 安原修一郎, 佐藤辰男, 三浦 幸雄: 褐色細胞腫の全国集計および第 3 期ステロ イドホルモン産生異常症の全国集計について。「副 腎ホルモン産生異常症」調査研究班, 昭和60年度報 告書, p. $6-26,1986$.

4）大池正宏, 後藤一紀, 柳瀬俊彦，土師正文，大橋昌 夫, 名和田新, 加藤堅一, 井林 博：濃厚な遺伝性 を示した家族性褐色細胞腫の一家系. 臨床と研究, 65, 1217-1222, 1988.

5）小林哲郎，田中規文，辛 栄成，馬場将至，玉木康 博, 宮内啓輔, 芝 栄一, 高井新一郎, 森 武貞: MEN 2 型の褐色細胞腫：一側副腎摘出の選択. 内分泌外科，8，407-410，1991.

6）畠亮, 馬場志郎, 田崎 寛：両側性副腎腫瘍に 対する正常組織温存手術. 内分泌外科，6, 339$342,1989$.

7）㝨和田滋, 鈴木 誠, 阿曾佳郎：術前·術後の処置 一クッシング症候群一. 泌尿器外科, 2, 459-466, 1989.

8）中井利昭：褐色細胞臐一病態生理一. 泌尿器外科, 2, 1205-1211, 1989.

9) Remine, W.H., Chong, G.C., Heerden, J.A., Sheps, S.G. and Harrison, E.G. : Current management of pheochromocytoma. Ann. Surg., 179, 740-748, 1974.

10）八木 誠，柴垣一夫，木村貴彦，神田雄史，徳沢英 哲, 戸塚哲男, 矢田貝凱, 羽白 洸, 近藤真言, 播 岡徳也，利光 敞： 23 年後に再発を来した家族性 褐色細胞腫の 1 例. 日臨外医会誌, 50, 1625-1630, 1989.

11）中田瑛浩, 沢村俊宏：褐色細胞腫の基礎と臨床. 日 泌尿会誌，83，157-173，1992.

(1995年12月8日受付，1996年4月3日受理) 